\title{
Incidence of subclinical mastitis in Dutch dairy heifers in the first 100 days in lactation and associated risk factors
}

\author{
I. M. G. A. Santman-Berends, ${ }^{* 1}$ R. G. M. Olde Riekerink, ${ }^{*}$ O. C. Sampimon, ${ }^{\star 2}$ G. van Schaik, ${ }^{*}$ \\ and T. J. G. M. Lam† \\ ${ }^{*}$ GD Animal Health Service, PO Box 9, 7400AA Deventer, the Netherlands \\ †Department of Farm Animal Health, Faculty of Veterinary Medicine, Utrecht University, PO Box 80151, 3508 TD Utrecht, the Netherlands
}

\begin{abstract}
Heifer mastitis is a problem and risk factors may differ between heifers and older cows. The aim of this study was to estimate the heifer subclinical mastitis (HSCLM) incidence based on elevated somatic cell count (SCC) in the first $100 \mathrm{~d}$ in lactation and the associated risk factors in Dutch dairy herds. In 2008, 173 farmers filled in a questionnaire regarding housing and herd management factors potentially related to udder health. In addition, monthly milk production and SCC data from all cattle were provided by the Dutch Royal Cattle Syndicate (CRV, Arnhem, the Netherlands). Heifer subclinical mastitis incidence was calculated at the herd level as the number of heifer cases divided by the number of heifers at risk in the first $100 \mathrm{~d}$ in milk. Linear regression models were used for the analyses. On average, $25.5 \%$ [95\% confidence interval (CI): 23.9 to $27.0 \%$ ] of the heifers had subclinical mastitis. Heifers with a high SCC $(>150,000$ cells $/ \mathrm{mL})$ on the first test day after calving that returned to SCC levels below the cut-off continued to have a higher SCC throughout the study period compared with heifers with a low SCC $(\leq 150,000$ cells $/ \mathrm{mL})$ at the first test day after calving. Housing heifers together with lactating cows close to calving was protective from HSCLM incidence compared with separate housing (-4.5\%; $95 \%$ CI: -8.7 to $-0.2 \%)$. In addition, herds in which the farmer removed supernumerary teats of calves had a $7.0 \%$ (95\% CI: 2.8 to $11.3 \%$ ) lower HSCLM incidence and day and night grazing was also protective $(-5.9 \%$; $95 \%$ CI: -10.6 to $-1.3 \%)$. Herds that were milked with an automatic milking system had, on average, a $6.9 \%$ (95\% CI: 2.2 to $11.5 \%$ ) higher HSCLM incidence and submitting milk samples for bacteriological culturing in the previous year was also associated with a higher
\end{abstract}

\footnotetext{
Received July 26, 2011.

Accepted December 5, 2011.

${ }^{1}$ Corresponding author: i.berends@gddeventer.com

${ }^{2}$ Current address: Pfizer Animal Health, Postbus 372900 AA Capelle aan den IJssel, the Netherlands.
}

HSCLM incidence (4.1\%; 95\% CI: 1.1 to $7.1 \%$ ). Heifer subclinical mastitis is prevalent in all dairy herds, with a large variation in incidence. A high SCC in heifers at the first test day after calving appears to indicate a prolonged effect on udder health. Several management factors were found to be associated with HSCLM incidence that may help in reducing HSCLM.

Key words: heifer, subclinical mastitis, incidence, risk factor

\section{INTRODUCTION}

Udder health is highly correlated to productivity, antibiotic use, and animal welfare and is, therefore, important for the dairy industry. Subclinical mastitis (SCLM) in heifers is an indicator for udder health and has been associated with production losses, higher probabilities of clinical mastitis, and culling (De Vliegher et al., 2005; Whist et al., 2007; Steeneveld et al., 2008). As a result, SCLM causes economic losses for the farmer (Huijps et al., 2009). A cow with SCLM has no clinically detectable abnormalities in the udder and the milk appears normal. However, the SCC of a cow with SCLM is too high. The threshold that is used to diagnose a cow having SCLM varies among studies (Schukken et al., 2003; de Haas et al., 2008; Sampimon et al., 2010). In the Netherlands, a threshold of $>250,000$ cells $/ \mathrm{mL}$ is commonly used to diagnose SCLM in multiparous cows, whereas $>150,000$ cells/ $\mathrm{mL}$ is used in heifers (CRV, 2010; Sampimon et al., 2010). Several studies describe the association between SCC in bulk milk and management characteristics (Barkema et al., 1998, 1999b; De Vliegher et al., 2004; Plozza et al., 2011).

The majority of dairy farmers in the Netherlands report that they experience problems with both heifer SCLM (HSCLM) and heifer clinical mastitis, especially in the first period after calving. In European studies, the prevalence of HSCLM ranges between 18.1 and $35 \%$ at the start of the lactation (De Vliegher et al., 2001; Svensson et al., 2006). However, the exact percentage of heifers developing heifer mastitis in the Netherlands 
is not known. The etiology of heifer mastitis is often not understood by farmers because the udders of heifers have not been in contact with hands or milking machines. Udders of heifers can already be infected with mastitis pathogens before their first calving (Fox, 2009). This can lead to an elevated SCC or clinical mastitis after calving. Additionally, if infected heifers are introduced in the group of lactating cows, they can be a source for further transmission of bacteria. In the Netherlands, more than $20 \%$ of heifers have an SCC $>150,000$ cells $/ \mathrm{mL}$ at the first test day. In addition, $16 \%$ of heifers developed clinical mastitis during their first lactation, of which $40 \%$ occurred in the first month of lactation (Miltenburg et al., 1996; Barkema et al., 1998).

Several risk factors for mastitis, such as hygiene, season, post-milking teat disinfection, grazing, and barn type (Barkema et al., 1999b; Olde Riekerink et al., 2007) are valid for both heifers and multiparous cows. However, heifers differ from multiparous cows with respect to dry period, production level, and nutrition before calving and may have specific risk factors for SCLM. In addition, risk factors with respect to the dry period, such as dry cow treatment and dry period mineral supplementation are not applicable to heifers. Therefore, heifer mastitis may have other etiology than mastitis in multiparous cows. Previously, risk factors such as feeding concentrates, housing, proportion of heifers with mastitis, and using restraint measures during milking, fly control strategy, contact with lactating cows before calving, and udder edema before calving were already identified in Sweden and Belgium (Svensson et al., 2006; Piepers et al., 2011). However, to what extent those risk factors may be applied to the farming system in the Netherlands is unknown. The aim of this study was to describe SCC and to identify the incidence of HSCLM in the first $100 \mathrm{~d}$ in lactation as well as associated risk factors in the Netherlands based on test-day records.

\section{MATERIALS AND METHODS}

\section{Sampled Population and Available Data}

Udder health was monitored in 380 dairy herds in the Netherlands between 2005 and 2009 as part of a national udder health program (van den Borne et al., 2010). These herds were a random representation of Dutch dairy herds with more than 50 lactating cows of which the herd owners were younger than $50 \mathrm{yr}$. In the spring of 2008, these farmers were asked to participate and complete a questionnaire in a study to determine risk factors for HSCLM. The questionnaire was validated before use on 5 dairy farms. In total, 189 farmers completed the questionnaire that was sent to them by regular mail or that was e-mailed between May and September 2008. Results of the questionnaire were entered in NETQ software (NetQuestionnaires Nederland BV, 2007), a program for the preparation of questionnaire data. Four weekly test-day records from all heifers in the study herds that were present in the period January to December 2008 were provided by the Dutch Royal Cattle Syndicate (CRV, Arnhem, the Netherlands) and contained the following cow and milk quality data: date of sampling; herd level: unique herd identification; cow level: identification number, date of calving, and parity; and test-day level: number of days in lactation, delivered kilograms of milk, fat, and protein, SCC, and predicted kilograms of milk, fat, and protein.

The data provided by CRV were aggregated to herd level and combined with the results of the questionnaire. The items included in the questionnaire are summarized in 7 categories of management practices in Table 1.

\section{Definitions}

The diagnosis HSCLM was based on individual SCC results in heifers between 4 and 100 DIM and was defined as SCC $>150,000$ cells $/ \mathrm{mL}$ at 1 or more of the regular test days (CRV, 2010; Sampimon et al., 2010). All test day results within the first 100 DIM were included because the majority of the IMI in that period probably originated from before, or at, calving (Bradley and Green, 2000). Heifers having a first elevated SCC after 100 DIM likely got infected during lactation and in those heifers, risk factors are probably similar to those for multiparous cows with SCLM. In addition, test-day results obtained within the first $4 \mathrm{~d}$ after calving were excluded from the analyses because an elevated SCC in the first days of lactation could have a physiological background rather than being caused by mastitis (Dohoo, 1993; Barkema et al., 1999a).

\section{Statistical Analyses}

The average SCC for heifers per test day in the first 100 DIM was estimated for 3 separate groups of heifers: 1) an elevated SCC at the first test-day measure and a low SCC $(\leq 150,000$ cells $/ \mathrm{mL})$ at subsequent test days (HLL group), 2) heifers that had an elevated SCC at all test days (HHH group), and 3) heifers that had a low SCC at all test days (LLL group). The natural logarithm of the SCC (lnSCC) was analyzed to determine whether the SCC of the LLL and the HLL 
Table 1. Summary of management factors in the questionnaire

\begin{tabular}{|c|c|}
\hline Management factor & Description \\
\hline Raising young stock & $\begin{array}{l}\text { Housing of young stock, treatments, moment of insemination, } \\
\text { method of feeding calves, type of milk fed to calves }\end{array}$ \\
\hline Grazing per group of cows ${ }^{1}$ & $\begin{array}{l}\text { Frequency, duration, parasite control of heifers during the outdoor season, } \\
\text { housing of pregnant heifers and dry cows during the outdoor season }\end{array}$ \\
\hline Milking process and technique & Number of milkers, udder preparation, milking procedures, hygiene in the milk parlor \\
\hline Mastitis and dry cow treatment & Preventive measures, types and amount of antibiotics used \\
\hline
\end{tabular}

${ }^{1}$ Groups of cows were calves $<2 \mathrm{wk}$, calves between 2 and 10 wk of age, calves between 10 wk of age and insemination, pregnant young stock between insemination and calving, heifers, and multiparous cows.

heifers differed significantly between 50 and 100 DIM to identify if the first test-day SCC has a prolonged effect on SCC. In this analysis, $\operatorname{lnSCC}$ was used as the dependent variable, the groups of heifers (HLL, LLL, and $\mathrm{HHH}$ ) were included as independent variables, milk production was included to correct for possible confounding, and the model was corrected for repeated measures of multiple test-day results within heifers. Because the residuals of $\operatorname{lnSCC}$ were normally distributed, a linear mixed model in SAS 9.1 (SAS Institute, 2006) was used for the analysis.

For the analyses of the risk factors, the test-day data were aggregated to HSCLM incidence per herd. The HSCLM incidence on herd level was calculated as the number of cases of HSCLM in the first $100 \mathrm{~d}$ after calving divided by the total number of heifers in the first $100 \mathrm{~d}$ of lactation that were present on the farm. The data of the HSCLM incidence was combined with the results of the questionnaire and descriptive statistics were performed to describe the HSCLM incidence in the first $100 \mathrm{~d}$ after calving.

In the risk factor analyses, management factors in the questionnaire that were hypothesized to be associated with HSCLM and potentially gave the farmer the possibility to intervene to reduce HSCLM were included. Because the results of the questionnaire concerning mastitis and dry cow treatment gave information on treatment of HSCLM instead of intervention measures for HSCLM, these were excluded from the analyses. The HSCLM incidence followed a normal distribution and, therefore, general linear models in SAS 9.1 (SAS Institute, 2006) were used for analyses. First, the variables derived from the questionnaire were subjected to univariable analyses. Variables with $P \leq 0.20$ were kept for the final multivariable model. The multivariable analysis was done using a backward elimination procedure. After each run, the variable with the highest $P$-value was excluded from the model until all variables had $P$ $\leq 0.05$. Confounding was monitored by the change in the coefficient of a variable after removing another variable. If the change of the estimates exceeded $25 \%$ or 0.1 when the value of the estimate was between -0.4 and 0.4 , the removed variable was considered a potential confounder and was re-entered in the model. The robustness of the final model was checked by carrying out the same procedure with forward selection. In the final model, all possible 2 -way interactions were tested. The residuals of the final model were tested for normality and the coefficient of determination $\left(\mathrm{r}^{2}\right)$ was calculated to measure the proportion of variance explained by the model. The model used was described as

$$
Y_{i}=\beta_{0}+\beta_{1} X_{1}+\beta_{2} X_{2}+\ldots \beta_{n} X_{n}+\varepsilon_{i},
$$

where $Y_{i}=$ HSCLM incidence, $\beta_{0}=$ intercept, $\beta_{n} X_{n}$ $=$ independent variables that are associated with the dependent variable $Y_{i}$, and $\varepsilon_{i}=$ standard error for each herd $i$.

\section{RESULTS}

\section{Descriptive Data}

During our study, 189 farmers completed the questionnaire. From 179 of the 189 dairy herds, SCLM information based on test-day records was available. Six farms were excluded because of incomplete data in the questionnaire and 173 herds remained. The complete data set contained 45,202 test-day records from 7,966 heifers that were present in the participating herds between January 1 and December 31, 2008. The average $\operatorname{lnSCC}$ of the HHH heifers, HLL heifers, and LLL heifers are presented in Figure 1.

The SCC of HLL heifers remained, on average, higher compared with LLL heifers. The average lnSCC between d 50 and 100 was 4.03 (SCC $=56,000$ cells/ 


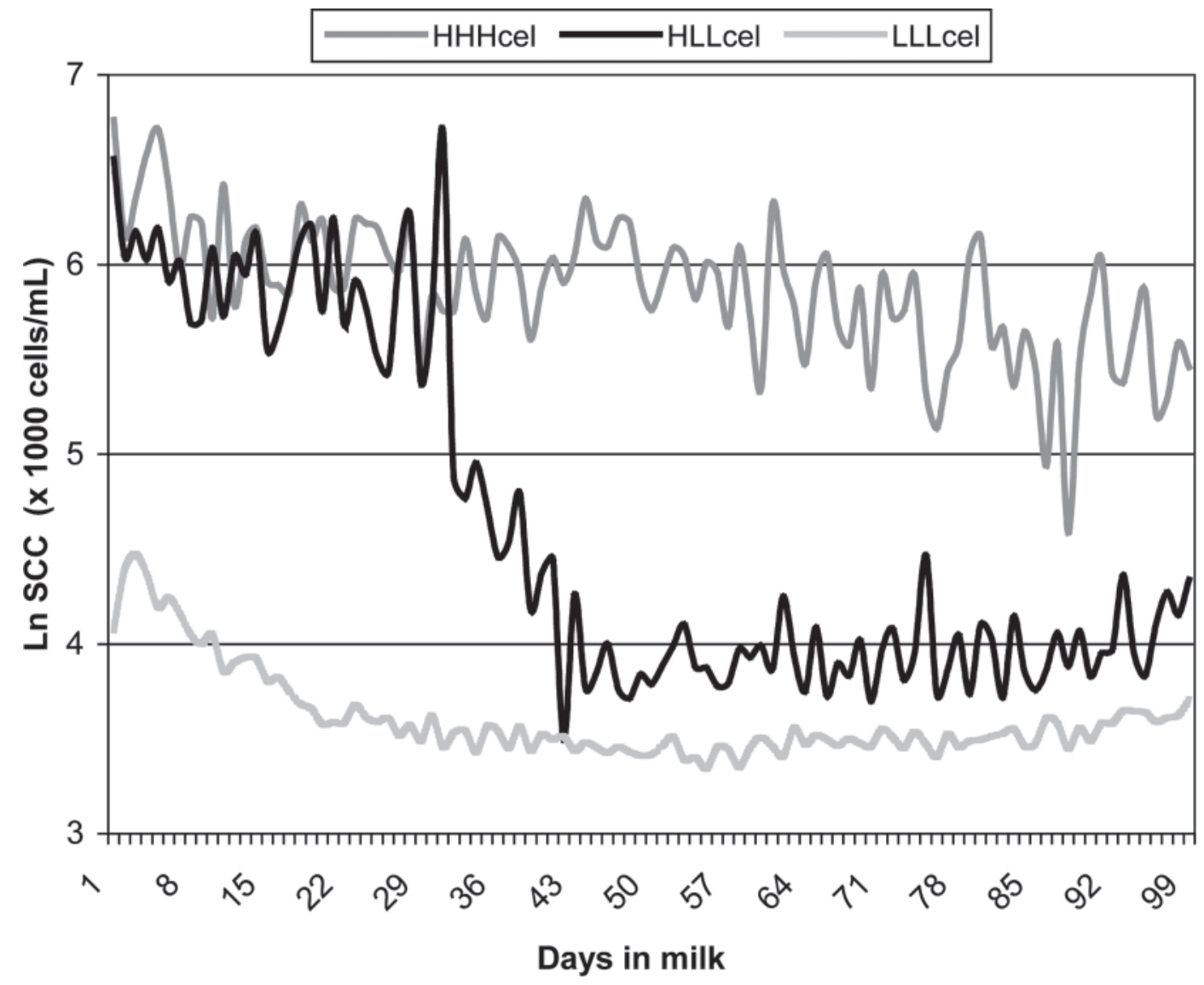

Figure 1. Mean natural logarithm of the SCC (lnSCC) in heifers with different test-day results in the first 100 DIM in 173 Dutch dairy herds [low SCC in all 3 test-day measures (LLLcel; $\mathrm{n}=5,935$ heifers), high SCC in all test-day measures (HHHcel; $\mathrm{n}=295$ heifers), and high SCC at the first test day and low SCC in the subsequent test days (HLLcel; $\mathrm{n}=813$ heifers)].

$\mathrm{mL})$ in HLL heifers and $3.55(\mathrm{SCC}=35,000$ cells $/ \mathrm{mL})$ in LLL heifers in the first 100 DIM. Whether the average $\operatorname{lnSCC}$ between the 2 groups with $\mathrm{SCC} \leq 150,000$ cells $/ \mathrm{mL}$ differed significantly from each other was analyzed while correcting for milk production and repeated test-day results, and was found to be highly significant (Z-test; $P<0.001$ ).

The average HSCLM incidence in the first $100 \mathrm{~d}$ of lactation was $25.5 \%$ (95\% CI: 23.9 to $27.0 \%$ ). Per herd, the HSCLM incidence varied between 0 and $60.3 \%$ (Figure 2). In total, $25.5 \%$ of the heifers had at least 1 episode of elevated SCC in the first 100 DIM. In $69 \%$ of these heifers, HSCLM was found at the first test-day measure $(69 \%$ of $25.5 \%=17.6 \%)$; in $19.3 \%$, HSCLM was found for the first time at the second test-day measure $(19.3 \%$ of $25.5 \%=4.9 \%)$; and in $11.8 \%$, HSCLM was found for the first time at the third test day $(11.8 \%$ of $25.5 \%=3.0 \%$; Figure 3 ).

New HSCLM cases in the first 100 DIM were mainly observed at the first test day. The elevated SCC returned in $59 \%(59 \%$ of $17.6 \%=10.2 \%)$ of the cases to

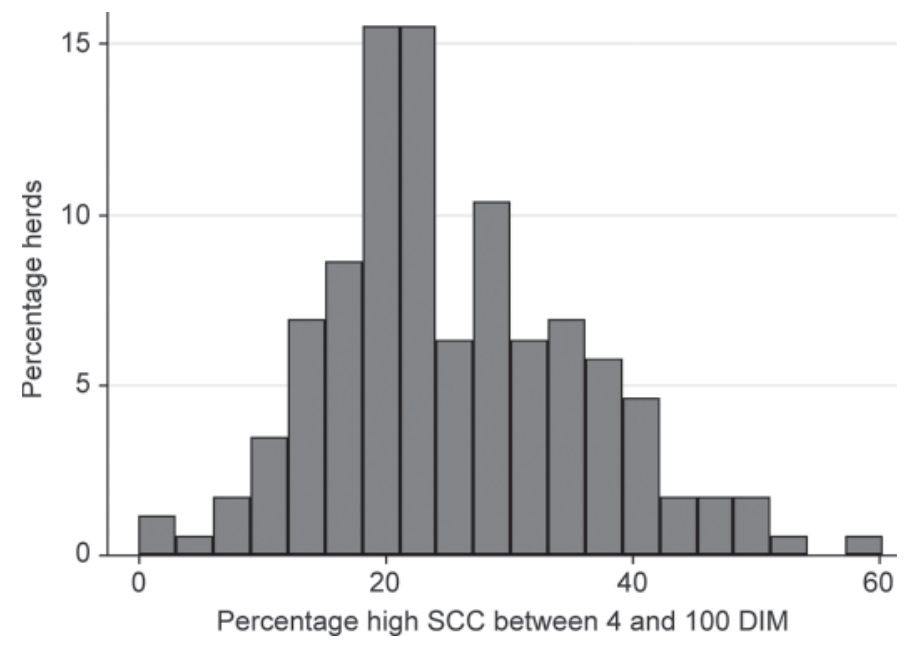

Figure 2. Frequency distribution of heifer subclinical mastitis incidence between 4 and $100 \mathrm{~d}$ in lactation in 173 Dutch dairy herds in 2008 . 


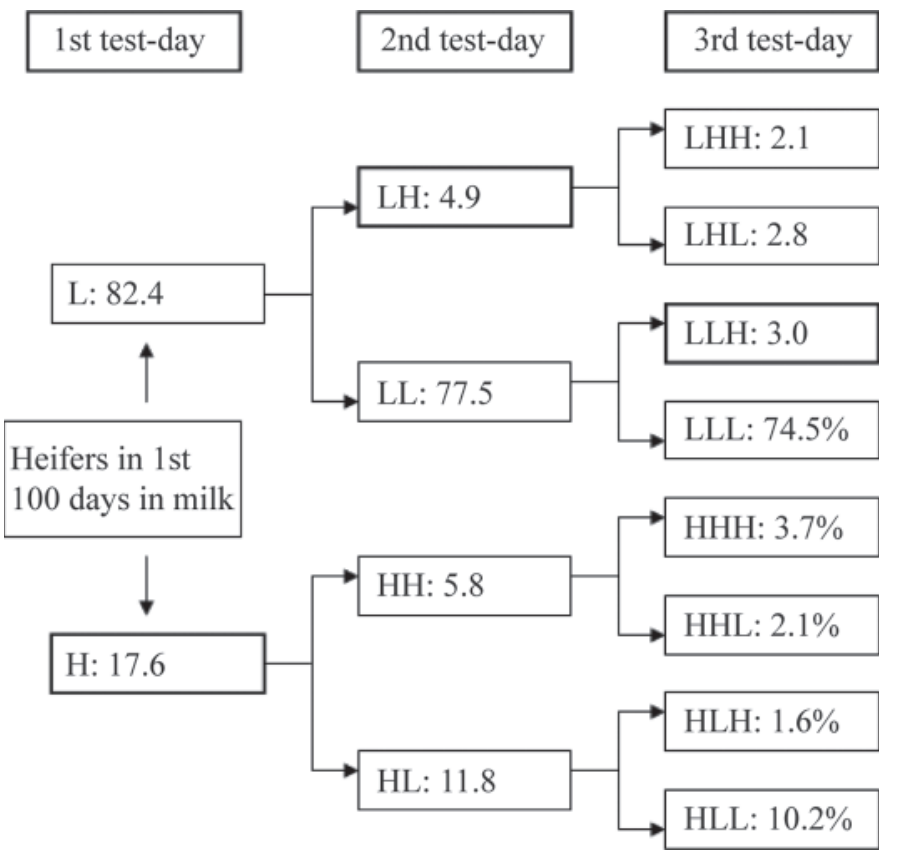

Figure 3. Outline of the percentage of heifers with subclinical mastitis per test-day record in the first 100 DIM in 7,966 heifers in 173 Dutch dairy herds. $\mathrm{L}=$ low $\mathrm{SCC}(\leq 150,000$ cells $/ \mathrm{mL}) ; \mathrm{H}=$ high $\mathrm{SCC}$ $(>150,000$ cells $/ \mathrm{mL}) ; \mathrm{LHH}=$ low $\mathrm{SCC}$ at the first test day and high SCC in the subsequent test days; LHL = low SCC at the first and third test days and high SCC at the second test day; LLH = low SCC at the first 2 test days and high SCC at the third test day; LLL = low SCC in all 3 test-day measures; $\mathrm{HHH}=$ high $\mathrm{SCC}$ in all test-day measures; HHL $=$ high SCC at the first 2 test days and low SCC at the third test day; HLH = high SCC at the first and third test days and low SCC at the second test day; HLL = high SCC at the first test day and low SCC in the subsequent test days. normal levels before the second test-day measure and remained low.

\section{Herd Management Risk Factors of HSCLM}

In the univariable model, 25 variables were related to HSCLM $(P \leq 0.20)$ and, therefore, entered the multivariable model (Table 2). In the final multivariable model, 5 factors remained and explained $24 \%$ of the variation in HSCLM incidence between herds (Table 3 ). Herds that housed heifers that were close to calving together with lactating cows had a lower HSCLM incidence $(-4.5 \% ; 95 \%$ CI: -8.7 to $-0.2 \%)$ than herds in which heifers were housed separately (Table 3). No effect was observed of keeping the pregnant heifers together with dry cows or other groups. Herds in which supernumerary teats of calves were removed at the same time as dehorning had a lower HSCLM incidence ( $-7.0 \%$; 95 CI: -11.3 to $-2.8 \%)$ compared with herds in which supernumerary teats were not removed. Furthermore, day and night grazing of lactating cows also was protective from HSCLM incidence $(-5.9 \% ; 95 \%$ CI: $-5.9 \%$ to $-1.3 \%$ ) compared with keeping the cows inside. Milking with an automatic milking system was found to be a risk factor for HSCLM incidence. Heifers in herds with an automatic milking system had a significant higher incidence of HSCLM (6.9\%; 95\% CI: 2.2 to $11.5 \%$ ). Finally, heifers from farmers that submitted milk samples for mastitis culturing in the previous year had a higher HSCLM incidence (Table 3).

Table 2. Risk factors associated with the incidence of heifer subclinical mastitis up to $100 \mathrm{~d}$ in lactation in 173 Dutch dairy farms in the univariable analyses $(P \leq 0.20)$

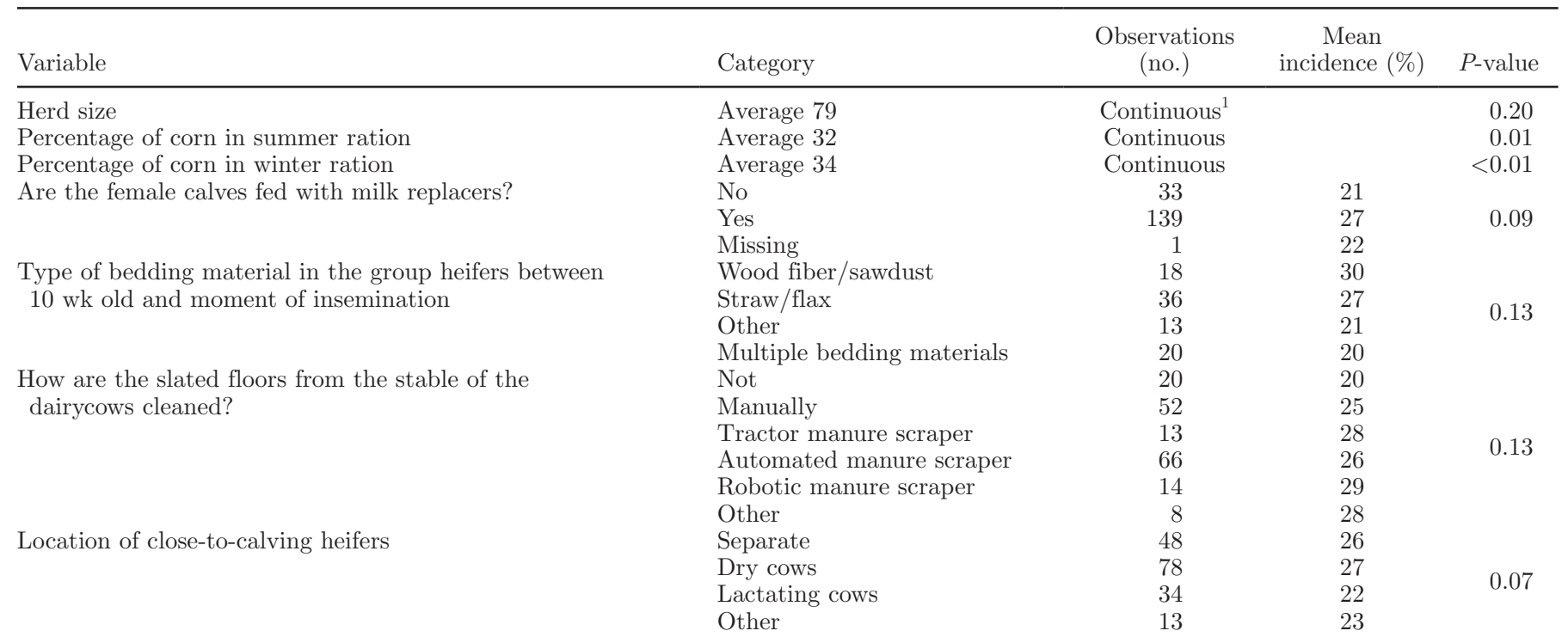


Table 2 (Continued). Risk factors associated with the incidence of heifer subclinical mastitis up to $100 \mathrm{~d}$ in lactation in 173 Dutch dairy farms in the univariable analyses $(P \leq 0.20)$

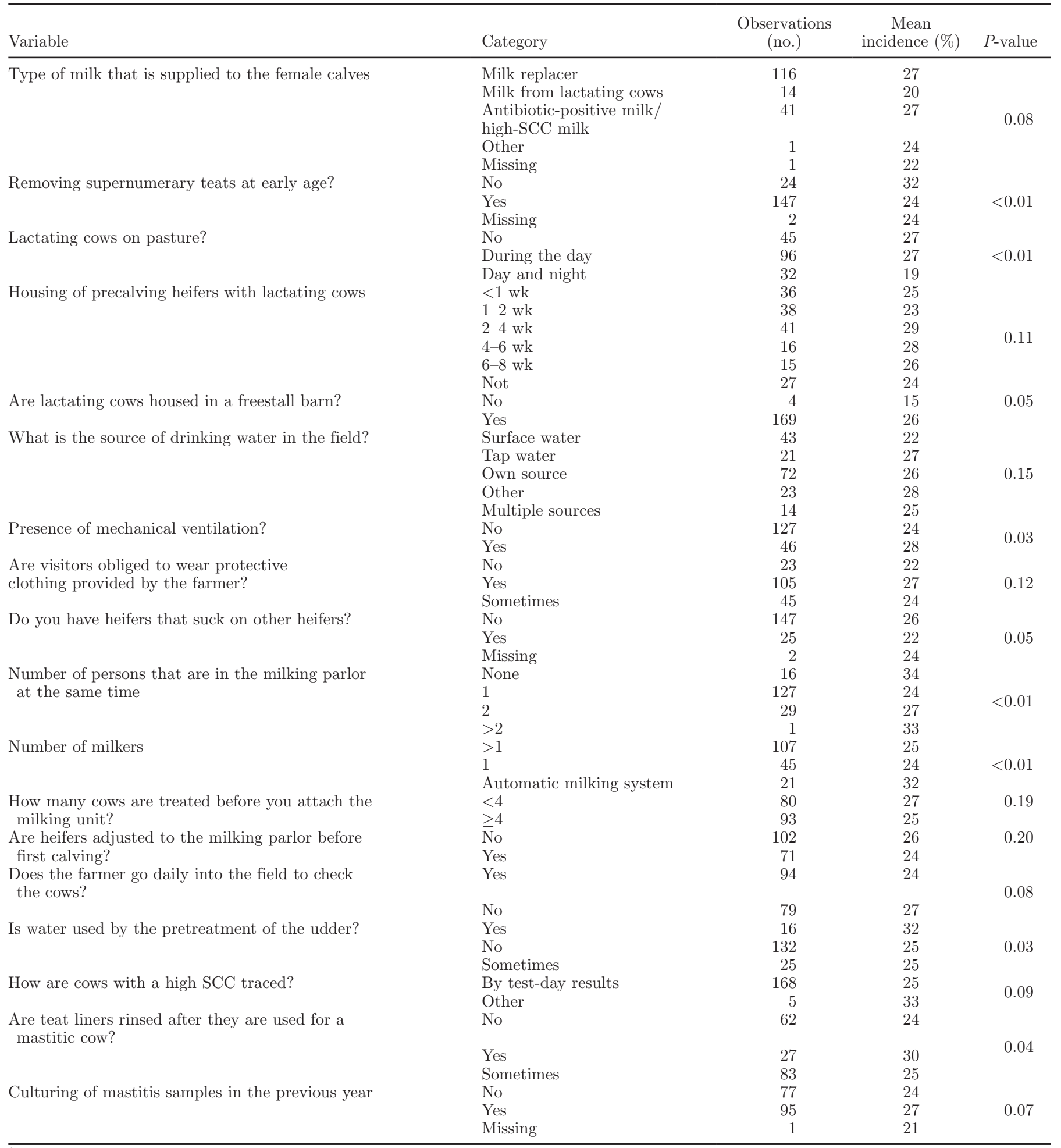

${ }^{1}$ Continuous (not categorical) variable; 173 observations for all continuous variables. 
Table 3. Risk factors associated with the incidence of heifer subclinical mastitis up to $100 \mathrm{~d}$ in lactation in 173 Dutch dairy farms

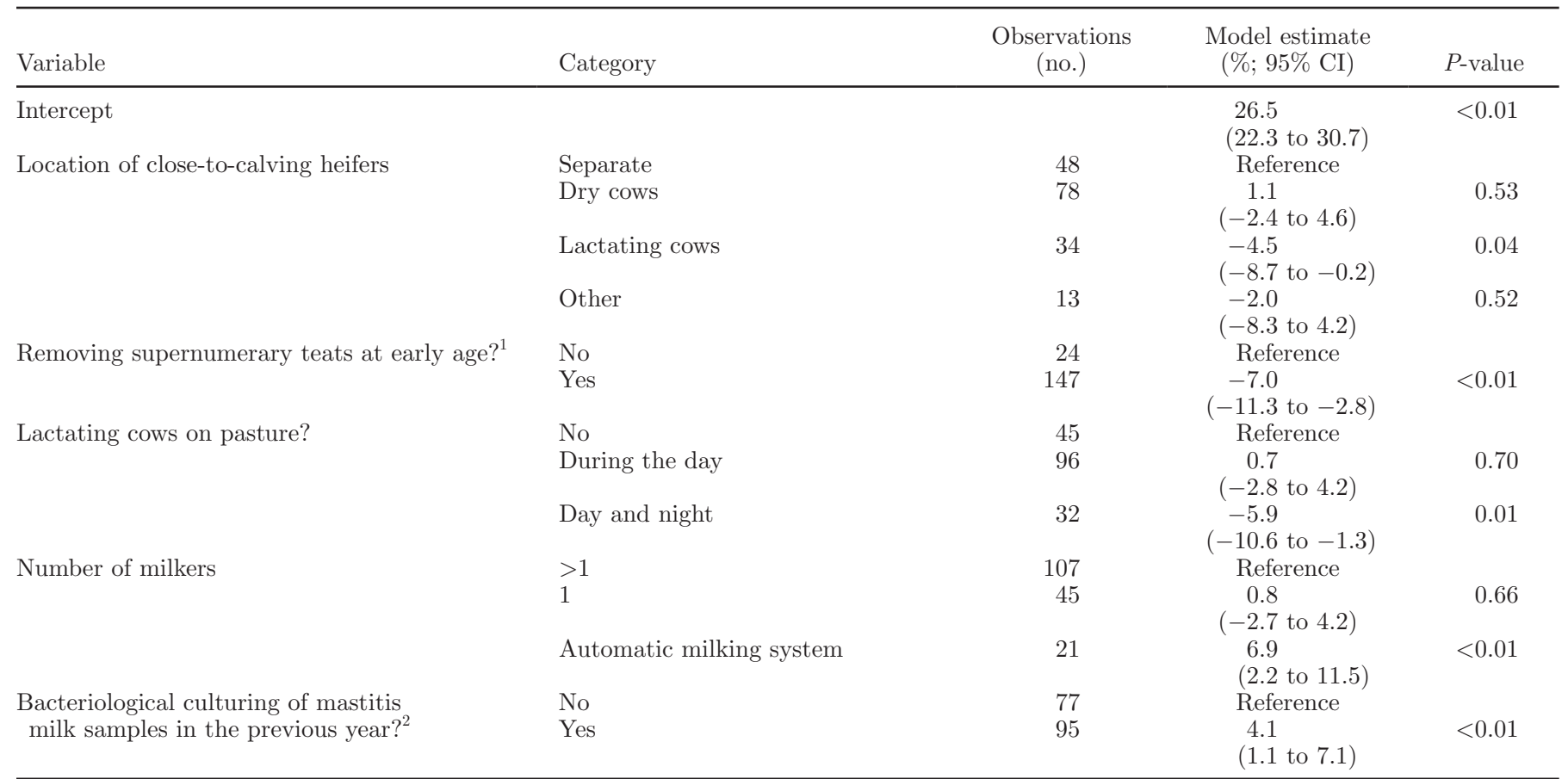

${ }^{1}$ Two observations were missing and were included as a separate category; these results did not differ significantly from the reference category and were not presented.

${ }^{2}$ One observation was missing and was included as a separate category; the result of this category did not differ significantly from the reference category and was not presented.

\section{DISCUSSION}

In this study, the average HSCLM incidence was $25.5 \%$ (95\% CI: 23.9 to $27.0 \%$ ) in the first 100 DIM, with $17.6 \%$ of the heifers having a high SCC on the first test day. This was comparable with the results of Svensson et al. (2006). They found that $18.1 \%$ of the heifers had a high SCC ( $>200.000$ cells $/ \mathrm{mL})$ at the first test day. However, De Vliegher et al. (2001) found a SCC $>150,000$ cells $/ \mathrm{mL}$ in $35 \%$ of the heifers at risk. In their study, they included only heifers with a test-day result during the period 5 to $14 \mathrm{~d}$ after calving, whereas in our study, the test-day results obtained between 4 and $100 \mathrm{~d}$ after calving were included. Nevertheless, we found that the HSCLM incidence in the first $100 \mathrm{~d}$ after lactation showed large variation between herds. In our analyses, the first 4 DIM were excluded because it was assumed that a high SCC in these first days would not necessarily have been caused by mastitis pathogens. De Vliegher et al. (2001, 2004) also excluded the first 4 d from their analyses. However, Dohoo (1993) stated that using SCC results before 9 DIM could overestimate the prevalence of infected heifers in the herd. On the other hand, Barkema et al. (1999a) suggested that SCC results from a minimum of 2 DIM can be used for the determination of the udder health status. Because no absolute agreement exists on the number of days at the start of lactation that have to be excluded and because the higher SCC at the start of lactation seemed to stabilize within 4 DIM in our data, we decided to exclude only test-day results that were obtained in the first $4 \mathrm{~d}$ after calving.

If heifers were assigned to 1 of 3 SCC groups (HLL, $\mathrm{HHH}$, or LLL), it was found that the SCC of HLL heifers remained higher throughout the study period compared with LLL heifers. It might be that this high SCC in early lactation negatively influences milk production as described by De Vliegher et al. (2005), with the consequence that the SCC remains slightly higher. Another possibility is that, although SCC decreased, these heifers remained infected. This may lead to an increased risk of developing clinical mastitis later in lactation. This, however, was not studied by us and requires additional follow up.

In our study, 5 factors were associated with HSCLM incidence, of which 3 can be influenced by the farmers' day-to-day management. Bacteriological culturing of milk samples in the previous year was an additional factor. It is likely that this factor represented herds with previous mastitis problems rather than being a risk factor for HSCLM. It may be that the farmers of these herds are more likely to carry out diagnos- 
tics because of the high incidence of SCLM. Keeping close-to-calving heifers with the lactating cows appeared to be protective against HSCLM incidence. It is known that the first calving and the transition into lactation have a significant effect on heifers (Fox, 2009). It is possible that this transition is even more difficult when influenced by the stress of transferring the heifer to the lactating cows. Transferring heifers into the group of lactating cows earlier may lead to more adjustment time, probably less stress, and getting used to the lactation ration in an earlier stage compared with transferral after calving. The removal of supernumerary teats in calves was also found to reduce the incidence rate of HSCLM. This factor might be directly related to a lower HSCLM incidence because potential inflammation of these supernumerary teats is prevented. It may, however, also be an indirect relation, being related to the management style. Farmers that remove supernumerary teats may be more precise and have a more hygienic management style or may have more focus on udder health and, therefore, have lower HSCLM incidence (Barkema et al., 1999b). Herds in which the lactating cows were grazed day and night had less HSCLM than herds in which all lactating cows remained indoors. The infection pressure in the field may be lower than in the barn, possibly leading to fewer new infections and SCLM in heifers. Olde Riekerink et al. (2007) showed that cows that grazed during the summer had a lower incidence rate of clinical mastitis than cows that were kept confined. Heifer SCLM incidence in cattle that were only grazed during the day did not differ from cattle that remained indoors. The last factor that was found to be associated with HSCLM incidence was the number of milkers that are present during milking. Milking with an automatic milking system appeared to be a risk factor for incidence rate of HSCLM. This negative effect of an automatic milking system might be associated with the hierarchy in the herd. Optimal cow traffic is necessary if an automatic milking system is used, to obtain an optimal number of milkings (Svennersten-Sjaunja and Pettersson, 2008). When fresh-milked heifers enter the group of lactating cows, they may experience problems with reaching the automatic milking system and the automatic milking system may experience problems with adjusting to the new cow (Miller et al., 1995). Furthermore, the heifers have to get used to the automatic milking system, which might lead to incomplete milkings and prolonged intervals between milkings that negatively affect the udder health. However, a study conducted in the Netherlands comparing conventional and automatic milking parlors could not find differences in behavioral and physiological responses in heifers (Hopster et al., 2002).
Nevertheless, in dairy herds with automatic milking systems, udder health is, in general, not as good as in herds with conventional milking systems (Hovinen and Pyörälä, 2011). Automatic milking systems are less effective in teat cleaning than manual teat cleaning (Mottram, 1997; Hovinen et al., 2005) and the detection of (sub)clinical mastitis in automatic milking systems is not optimal (Hovinen and Pyörälä, 2011).

\section{CONCLUSIONS}

Heifer SCLM incidence occurs in almost all herds, in, on average, $25.5 \%$ of the heifers in the first $100 \mathrm{~d}$ of lactation. The SCC of HLL heifers remained higher than the SCC of LLL heifers. This showed that HSCLM at the first test day after calving is indicative for decreased udder health at a later stage of lactation. A higher HSCLM incidence rate was found in herds that submitted milk samples for bacterial culturing in the year before this study. This indicates that the incidence of heifer mastitis is higher in herds with prolonged mastitis problems. In addition, 3 management factors existed: removing supernumerary teats; housing heifers that were close to calving together with lactating cows; and day and night grazing of lactating cows, for which intervention could be performed to reduce HSCLM. Finally, the HSCLM incidence rate in herds that were milked with an automatic milking system was higher than those with conventional milking systems.

\section{ACKNOWLEDGMENTS}

This study was financially supported by the Dutch Dairy Board (Zoetermeer, the Netherlands). The authors acknowledge the farmers for participating in the study and the Royal Cattle Syndicate (CRV, Arnhem, the Netherlands) for providing test-day records.

\section{REFERENCES}

Barkema, H. W., H. Deluyker, Y. H. Schukken, and T. G. J. M. Lam. 1999b. Quarter-milk somatic cell count at calving and at the first six milkings after calving. Prev. Vet. Med. 38:1-9.

Barkema, H. W., Y. H. Schukken, T. J. G. M. Lam, M. L. Beiboer, G. Benedictus, and A. Brand. 1998. Management practices associated with low, medium, and high somatic cell counts in bulk milk. J. Dairy Sci. 81:1917-1927.

Barkema, H. W., J. D. Van der Ploeg, Y. H. Schukken, T. J. G. M. Lam, G. Benedictus, and A. Brand. 1999a. Management style and its association with bulk milk somatic cell count and incidence rate of clinical mastitis. J. Dairy Sci. 82:1655-1663.

Bradley, A. J., and M. J. Green. 2000. A study of the incidence and significance of intramammary enterobacterial infections acquired during the dry period. J. Dairy Sci. 83:1957-1965.

CRV (Dutch Royal Cattle Syndicate). 2010. Definitions of somatic cell count. Accessed May 25, 2011. https://www.crv4all.nl/support/ help/modules/mpr-uitslag/52934. 
de Haas, Y., W. Ouweltjes, J. ten Napel, J. J. Windig, and G. de Jong. 2008. Alternative somatic cell count traits as mastitis indicators for genetic selection. J. Dairy Sci. 91:2501-2511.

De Vliegher, S., H. W. Barkema, H. Stryhn, G. Opsomer, and A. de Kruif. 2005. Impact of early lactation somatic cell count in heifers on milk yield over the first lactation. J. Dairy Sci. 88:938-947.

De Vliegher, S., H. Laevens, H. W. Barkema, I. R. Dohoo, H. Stryhn, G. Opsomer, and A. de Kruif. 2004. Management practices and heifer characteristics associated with early lactation somatic cell count of Belgian dairy heifers. J. Dairy Sci. 87:3672-3682.

De Vliegher, S., H. Laevens, G. Opsomer, E. de Muêlenaere, and A. de Kruif. 2001. Somatic cell count in dairy heifers during early lactation. Vlaams Diergeneeskundig Tijdschrift 70:212-215.

Dohoo, I. R. 1993. An evaluation of the validity of individual cow somatic cell counts from cows in early lactation. Prev. Vet. Med. 16:103-110.

Fox, L. K. 2009. Prevalence, incidence and risk factors of heifer mastitis. Vet. Microbiol. 134:82-88.

Hopster, H., R. M. Bruckmaier, J. T. N. Van der Werf, S. M. Korte, J. Macuhova, G. Korte-Bouws, and C. G. van Reenen. 2002. Stress responses during milking; comparing conventional and automatic milking in primiparous dairy cows. J. Dairy Sci. 85:3206-3216.

Hovinen, M., A.-M. Aisla, and S. Pyörälä. 2005. Visual detection of technical success and effectiveness of teat cleaning in two automatic milking systems. J. Dairy Sci. 88:3354-3362.

Hovinen, M., and S. Pyörälä. 2011. Invited review: Udder health of dairy cows in automatic milking. J. Dairy Sci. 94:547-562.

Huijps, K., S. de Vliegher, T. J. G. M. Lam, and H. Hogeveen. 2009. Cost estimation of heifer mastitis in early lactation by stochastic modeling. Vet. Microbiol. 134:121-127.

Miller, R. H., L. A. Fulton, B. Erez, W. F. Williams, and R. E. Pearson. 1995. Variation in distances among teats of Holstein cows: Implications for automated milking. J. Dairy Sci. 78:1456-1462.

Miltenburg, J. D., D. de Lange, A. P. P. Crauwels, J. H. Bongers, M. J. M. Tielen, Y. H. Schukken, and A. R. W. Elbers. 1996. Incidence of clinical mastitis in a random sample of dairy herds in the southern Netherlands. Vet. Rec. 139:204-207.

Mottram, T. 1997. Requirements for teat inspection and cleaning in automatic milking systems. Comput. Electron. Agric. 17:63-77.
NetQuestionnaires Nederland BV. 2007. Manual NETQ Internet Surveys 6.0. NetQuestionnaires Nederland BV, Utrecht, the Netherlands.

Olde Riekerink, R. G. M., H. W. Barkema, and H. W. Stryhn. 2007. The effect of season on somatic cell count and the incidence of clinical mastitis. J. Dairy Sci. 90:1704-1715.

Piepers, S., K. Peeters, G. Opsomer, H. W. Barkema, K. Frankena, and S. De Vliegher. 2011. Pathogen group specific risk factors at herd, heifer and quarter levels for intramammary infections in early lactating dairy heifers. Prev. Vet. Med. 99:91-101.

Plozza, K., J. J. Lievaart, G. Potts, and H. W. Barkema. 2011. Subclinical mastitis and associated risk factors on dairy farms in New South Wales. Aust. Vet. J. 89:41-46.

Sampimon, O., B. H. van den Borne, I. Santman-Berends, H. W. Barkema, and T. J. G. M. Lam. 2010. Effect of coagulase-negative staphylococci on somatic cell count in Dutch dairy herds. J. Dairy Res. 77:318-324.

SAS Institute. 2006. SAS/STAT1 9.1 User's Guide. SAS Institute Inc., Cary, NC

Schukken, Y. H., D. J. Wilson, F. Welcome, L. Garrison-Tikofsky, and R. N. Gonzalez. 2003. Monitoring udder health and milk quality using somatic cell counts. Vet. Res. 34:579-596.

Steeneveld, W., H. Hogeveen, H. W. Barkema, J. van den Broek, and R. B. M. Huirne. 2008. The influence of cow factors on the incidence of clinical mastitis in dairy cows. J. Dairy Sci. 91:13911402

Svennersten-Sjaunja, K. M., and G. Pettersson. 2008. Pros and cons of automatic milking in Europe. J. Anim. Sci. 86:37-46.

Svensson, C., A.-K. Nyman, K. Persson Waller, and U. Emanuelson. 2006. Effects of housing, management and health of dairy heifers on first-lactation udder health in southwest Sweden. J. Dairy Sci 89:1990-1999.

van den Borne, B. H. P., G. van Schaik, T. J. G. M. Lam, and M. Nielen. 2010. Variation in herd level mastitis indicators between primiand multiparae in Dutch dairy herds. Prev. Vet. Med. 96:49-55.

Whist, A. C., O. Østerås, and L. Sølverød. 2007. Streptococcus dysgalactiae isolates at calving and lactation performance within the same lactation. J. Dairy Sci. 90:766-778. 